\title{
Open Access Publication Status of Educational Technology with The Bibliometrics Approach
}

\author{
Fatkul Anam, Wijaya Kusuma University Surabaya, Surabaya, 60225, Indonesia, fatkulanam@yahoo.co.id \\ Andre Septianto, Nahdlatul Ulama University Sidoarjo, Sidoarjo, 61218, Indonesia, \\ andreseptianto1011@gmail.com \\ Mega Firdaus, Nahdlatul Ulama University Sidoarjo, Sidoarjo, 61218, Indonesia, megafirdaus22@gmail.com \\ Nur Asitah, Nahdlatul Ulama University Sidoarjo, Sidoarjo, 61218, Indonesia, nurasitah@gmail.com \\ Agung Purnomo, Bina Nusantara University, Jakarta, 11480, Indonesia, agung.purnomo@binus.ac.id
}

\begin{abstract}
The study aims to map the status of open access to scientific publications globally in the field of "educational technology." The study obtains data from Scopus using the document search service. Researchers analyze it using the bibliometric approach using Scopus analysis features and VoSviewer applications, namely document cited, publication growth, author, author network, country, type, institution affiliation, subject area, keyword network, and source. The study identifies keywords related to educational technology to search for and identify related articles from the Scopus database with 1,675 academic documents published from 1969 to 2019. From the study, we could find a trend towards an increasing number of open access research in "educational technology" every year globally. Author, country, type, institution affiliation, subject area, and source with the most publications were Peres, H.H.C., USA, article, Universidade de Sao Paulo, social science and Australasian Journal of Educational Technology.
\end{abstract}

Keywords: Educational Technology, Bibliometric, Education, Scopus, VOSviewer, Open Access. Received: 06.12.2020 Accepted: 10.01.2021

Published: 03.02.2021

\section{INTRODUCTION}

Education is increasingly interesting and challenging in the era of globalization. Globalization has placed it in a very strategic position as a determinant of the progress of a nation. Education's quality is needed for various fields of humanity, namely politics, diplomacy, industry, trade, science, technology, media, information technology, and culture. Thus, each student must achieve a high education to achieve the quality of continuing Education (Iskandar et al., 2018). Also, Education is among the standards for developed and developing countries to participate in this global era (Jamilah, 2016). Higher Education in the worldwide era faces enormous challenges from within and outside institutions. The difference in education level is one of many factors for the big difference in economic performance between developed and developing countries (Abdullah and Bhuiyan, 2019). Students face a myriad of challenges in the global era, unlike those faced by students in previous generations. Many of the educational challenges are beyond the control of professional educators (Davis, 2019). Education for humans acts as a media process guide to achieve safety, independence, social responsibility, and happiness by utilizing technology.

Educational technology has become one of the many main aspects of Education for humanity. Because digital technology in Education as part of educational technology can influence all areas of the student experience in teaching and learning. It has also been linked to improvements in student engagement, affective and cognitive behavior, and facilitation, which is the educators' main issue. There are a complicated relationship and interaction between technology and student involvement (Bond et al., 2020). International recognition of the importance of information technology, communication, and digital literacy skills has increased. Also, there is an increase in awareness of the recognition of the urgency of citizenship (Choi et al., 2017) and interdisciplinary and collaborative development (Barak, 2018) (Oliver and Jorre de St Jorre, 2018). Educational technology usage can create teaching and learning functions more intensive, self-efficacy, and increase student self-regulation (Alison and Delialioğlu, 2019). Educational technology can strengthen greater teaching. Educational technology researchers have struggled to find common definitions and terminology that can be used to share about student engagement in technology-based learning (Appleton et al., 2008). Modern educational technology has a role in helping continuous improvement in the quality of 
teaching. The development of learning methods is often not supported by changes in participant behavior. This disorder triggers reluctance to utilize new learning methods by some people (Widyasari et al., 2019). Some forms of educational technology development are Web 2.0, such as blogs, applications, social media, YouTube, learning management systems, online courses, etc.

The results of education technology research published in open access are very helpful and beneficial for researchers, students, and literature seekers. Open Access content refers to free and unlimited access to information and data online, such as journal articles and books. Open access content is open to all, even without the cost of access. Educational technology that synergizes with open access data can change the way people communicate and interact (Newman et al., 2016). Digital learning through technology that is modified by using persuasive concepts can increase student attention. Technology can improve the quality of learning and increase student knowledge (Suci et al., 2018). Internet, smartphones, and computers are an effective and efficient means of building communication between schools, parents, teachers, and students. Educational institutions based on educational technology have already been ready to take care of many things that were not previously handled easily because of geographical limits or sufficient ample technology (James Baxter, 2014).

The area of publication is generally educational technology limited to just one research topic. One example of the results of research by Melissa Bond has mapped research into student involvement in educational technology (Bond et al., 2020). Educational Technology Research is generally limited in schools (Czerniewicz et al., 2019), aspect (Medina et al., 2019) or country (Chaka and Nkhobo, 2019), or in one time period (Sutherland et al., 2012). There is no publication about open-access type education technology that shows the big picture visualized year after year with data from all countries. Also, there are no publications on educational technology in the type of open access that specifically address the relationship between affiliates, authors, probably the most cited, and also the impact of their research. The growth in how many academic documents related to the topic of open-access educational technology types that have been published and indexed by Scopus from 1969 to 2019 was 1,675 documents. Therefore, the study aims to map the status of open access to scientific publications globally in "educational technology."

\section{METHOD}

The study measures the status of open access type publication maps in "education technology" at the international level. Research data are obtained from the Scopus database using document search services in January 2020 with a bibliometric approach. Analysis and visualization of data use the analyze search results feature on the Scopus service and VOSViewer application (Setyawati et al., 2018). The VOSviewer tool is used to visualize and build bibliometric networks, visualize networks in researchers, countries, academic affiliations, growth in the number of studies, keywords, author collaboration, and research that was the most cited (Natakusumah, 2016). This study identified keywords related to open access educational technology to identify and search for related articles in the Scopus database with 1,675 academic documents published from 1969 to 2019 at the global level. The query command that was applied when mining data on Scopus was TITLE-ABS-KEY ("Educational Technology") AND PUBYEAR <2020 AND (LIMIT-TO (ACCESSTYPE(O.A.))).

\section{RESULT AND DISCUSSION}

\section{Document Cited of Educational Technology Publications}

The work of Kamel Boulos, M.N., Maramba, I., Wheeler, S. in 2006, entitled Wikis, blog, and podcast: A new generation of Web-Based tools for virtual collaborative clinical practice and Education is the most cited international publication of open access in educational technology. As a form of academic impact, it is mentioned by 668 documents. The top 10 most cited publications were shown in Table 1.

Table 1. Number of Citations from Open Access Publications in The Field of Educational Technology

\begin{tabular}{|l|l|l|l|l|l|}
\hline No & Document Title & Authors & Year & Source & Cited by \\
\hline 1. & Wikis, blog, and & Kamel Boulos, & 2006 & BMC Medical & 668 \\
& $\begin{array}{l}\text { podcast: A new } \\
\text { generation of Web- } \\
\text { Based tools for virtual } \\
\text { collaborative clinical }\end{array}$ & Wheeler, S. & & & \\
\hline
\end{tabular}




\begin{tabular}{|c|c|c|c|c|c|}
\hline & $\begin{array}{ll}\text { practice } & \text { and } \\
\text { education. } & \end{array}$ & & & & \\
\hline 2. & $\begin{array}{l}\text { Bio2RDF: Towards a } \\
\text { mashup to build } \\
\text { bioinformatics } \\
\text { knowledge systems. }\end{array}$ & $\begin{array}{l}\text { Bellau, F., Nolin, } \\
\text { M.-A., Touringny, } \\
\text { N., Rigault, P., } \\
\text { Morissette, J. }\end{array}$ & 2008 & $\begin{array}{l}\text { Journal of } \\
\text { Biomedical } \\
\text { Informatics. } \\
23(5) \text { pp.706- } \\
716\end{array}$ & 466 \\
\hline 3. & $\begin{array}{l}\text { The value of haptic } \\
\text { feedback in } \\
\text { conventional and } \\
\text { robot-assisted } \\
\text { minimal invasive } \\
\text { surgery and virtual } \\
\text { reality training: A } \\
\text { current review. }\end{array}$ & $\begin{array}{ll}\text { Van Der } & \text { Meijden, } \\
\text { o.A.J., } & \text { Schijven, } \\
\text { M.P. } & \end{array}$ & 2009 & $\begin{array}{l}\text { Surgical } \\
\text { Endoscopy. } \\
23(6) \text {, pp. } 1180- \\
1190\end{array}$ & 246 \\
\hline 4. & $\begin{array}{l}\text { Simulation technology } \\
\text { for skills training and } \\
\text { competency } \\
\text { assessment in medical } \\
\text { education. }\end{array}$ & $\begin{array}{lr}\text { Scalese, } & \text { R.J., } \\
\text { Obeso, } & \text { V.T., } \\
\text { Issenberg, S.B. } & \end{array}$ & 2008 & $\begin{array}{l}\text { Journal } r \text { of } \\
\text { general internal } \\
\text { medicine. } 23(1 \\
\text { SUPPL), pp. } 46- \\
49\end{array}$ & 234 \\
\hline 5. & $\begin{array}{l}\text { The cell-phone-based } \\
\text { platform for } \\
\text { biomedical device } \\
\text { development and } \\
\text { education application. }\end{array}$ & $\begin{array}{l}\text { Smith, Z.J., Chu, K., } \\
\text { Espenson, A.R., } \\
\text { (...), Matthews, D., } \\
\text { Wachsmann- } \\
\text { Hogiu, S. }\end{array}$ & 2011 & $\begin{array}{l}\text { PLoS ONE. } \\
6(3), \mathrm{e} 17150\end{array}$ & 218 \\
\hline 6. & $\begin{array}{l}\text { Computers and virtual } \\
\text { reality for surgical } \\
\text { education in the } 21^{\text {st }} \\
\text { century. }\end{array}$ & $\begin{array}{l}\text { Haluck, R.S., } \\
\text { Krummel, T.M. }\end{array}$ & 2000 & $\begin{array}{l}\text { Archive } r \text { of } \\
\text { Surgery. 135(7), } \\
\text { pp. 786-792 }\end{array}$ & 201 \\
\hline 7. & $\begin{array}{lr}\text { Physics. } & \text { PhET: } \\
\text { Simulations } & \text { that } \\
\text { enhance learning } & \end{array}$ & $\begin{array}{lr}\text { Wieman, } & \text { C.E., } \\
\text { Adams, } & \text { W.K., } \\
\text { Perkins, K.K. } & \\
\end{array}$ & 2008 & $\begin{array}{ll}\text { Science. } & \\
322(5902), \quad \text { pp. } \\
682-683\end{array}$ & 142 \\
\hline 8. & $\begin{array}{l}\text { Learning in a virtual } \\
\text { world: Experience } \\
\text { with using Second Life } \\
\text { for Medical Education. }\end{array}$ & $\begin{array}{l}\text { Wiecha, J., Heyden, } \\
\text { R., Sternthal, E., } \\
\text { Merialdi, M. }\end{array}$ & 2010 & $\begin{array}{l}\text { Journal of } \\
\text { Medical Internet } \\
\text { Research. 12(1) }\end{array}$ & 136 \\
\hline 9. & $\begin{array}{l}\text { Infusing active } \\
\text { learning into the large- } \\
\text { enrollment biology } \\
\text { class: seven strategies, } \\
\text { from the simple to } \\
\text { complex }\end{array}$ & $\begin{array}{l}\text { Allen, D., Tanner, } \\
\text { K. }\end{array}$ & 2000 & $\begin{array}{l}\text { Cell Biology } \\
\text { Education. } \\
\text { 4(WINTER), P.P. } \\
\text { 262-268 }\end{array}$ & 124 \\
\hline 10. & $\begin{array}{l}\text { Augmented Reality in } \\
\text { Surgery. }\end{array}$ & Shuhaiber, J.H. & 2004 & $\begin{array}{l}\text { Archives of } \\
\text { Surgery. } 139(2), \\
\text { pp. 170-174 }\end{array}$ & 122 \\
\hline
\end{tabular}




\section{Documents per Year from the Field of Educational Technology}

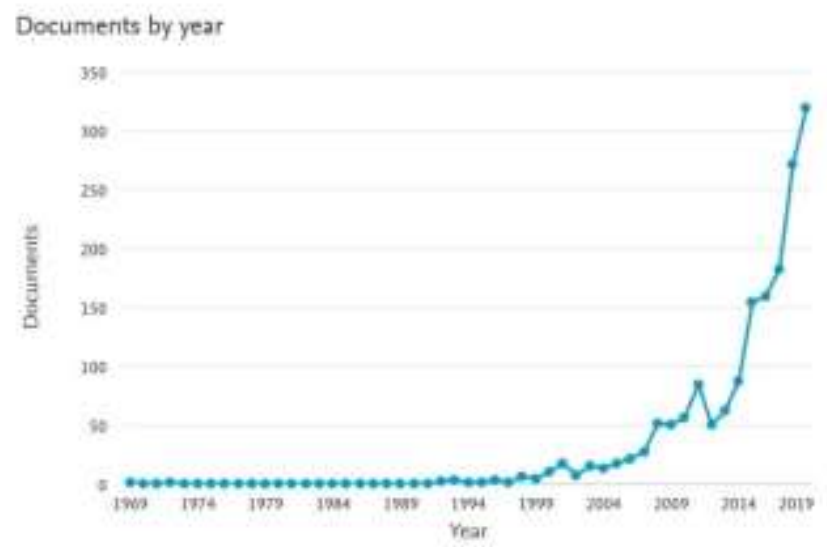

Figure 2. Number of Documents Per Year from the Field of Educational Technology

In general, the number of international publications on Educational Technology open access types has shown an increasing trend every year. Research on Educational Technology has been started since 1969. It can be seen in Figure 2. The number of documents per year in educational technology publications is 319 documents in 2019, 271 documents in 2018, 182 documents in 2017, 159 documents in 2016, and 154 documents in 2015.

\section{Most Individual Authors of Educational Technology}

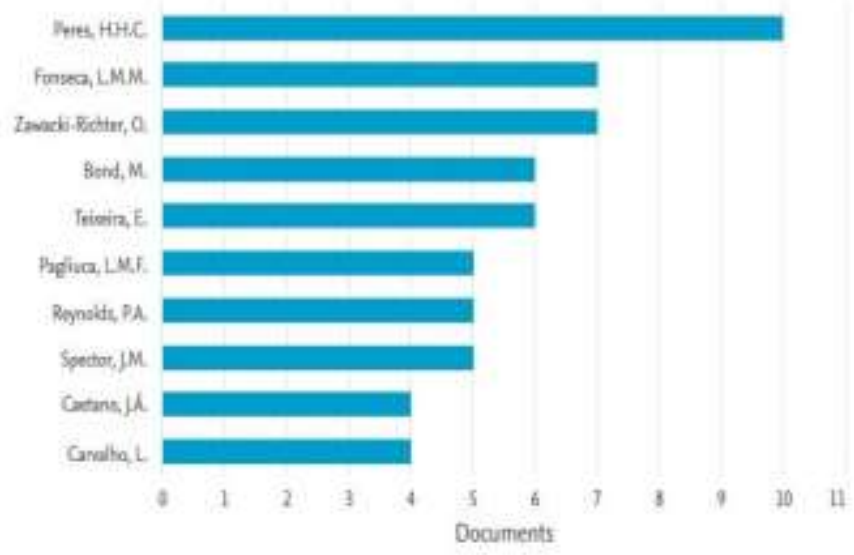

Figure 3. Most Individual Authors of Educational Technology

With the most open access publications in the field of Educational Technology, the author is Peres, H.H.C. with ten documents. Followed by Fonseca, L.M.M. 7 documents, Zawacki-Richter, 0. 7 documents, Bond, M. 6 documents, Teixeira, E. 6 documents, Pagliuca, L.M.F. 5 documents, Reynolds, P.A. 5 documents, Spector, J.M. 5 documents, Caetano, J.Á. 4 documents, and Carvalho, L. 4 documents.

\section{Author Collaboration Network}

There is a collaboration pattern between groups of researchers in Educational Technology, as seen in Figure 4, namely the red cluster containing Zawacki-Richter and Bond, M. A. 


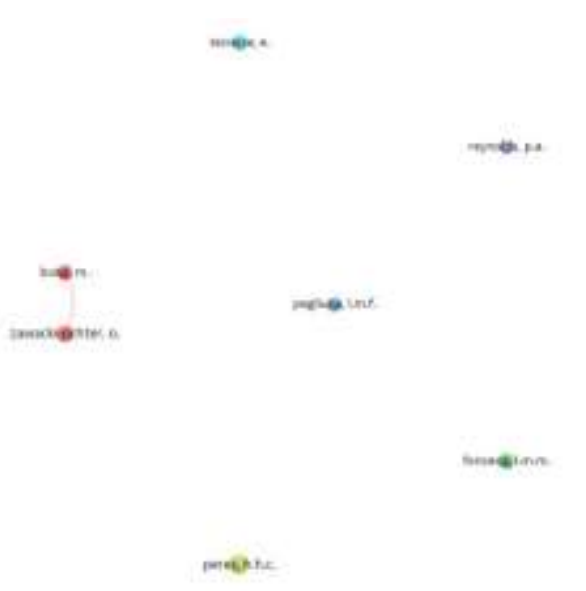

Figure 4. Author Collaboration Network

\section{Most Frequent Country Affiliation of Educational Technology Publication}

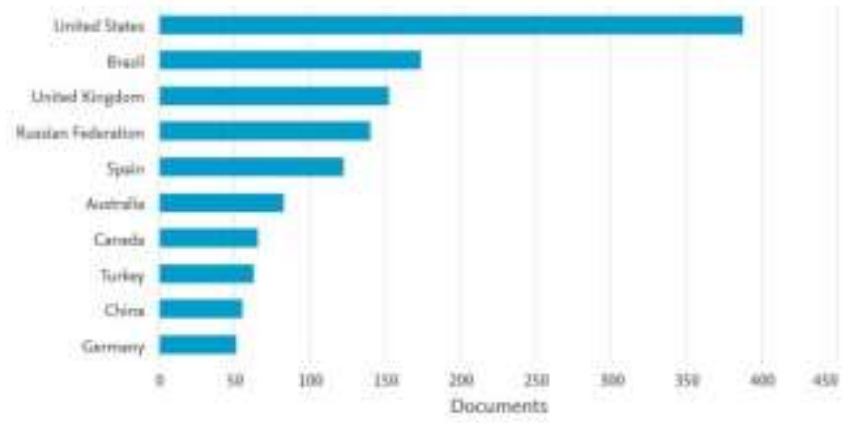

Figure 5. Country Number of Educational Technology Per Year

Figure 5, the country that has the most considerable contribution in open access publications in Educational Technology in the United States, has 387 documents. Followed by Brazil's 173 documents, UK 152 documents, Russian Federation 140 documents, Spain 122 documents, Australia 82 documents, Canada 65 documents, Turkey 62 documents, China 55 documents, and Germany 51 documents.

\section{Most Frequent Type Document of Educational Technology Publication}

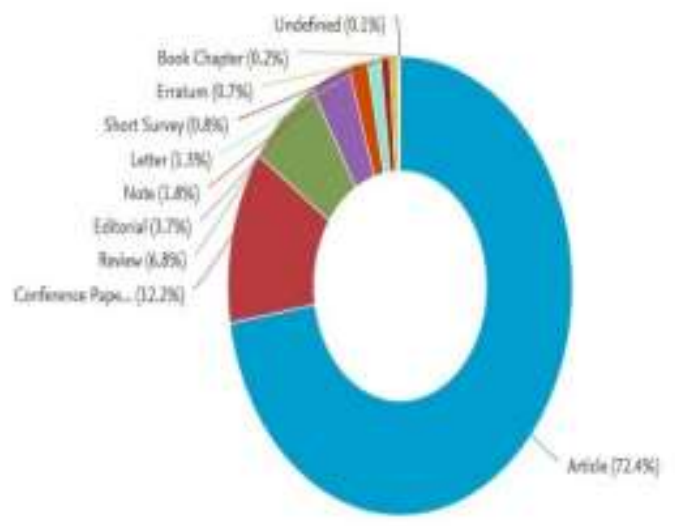

Figure 6. Most Frequent Type Document of Educational Technology Publication 
The most frequent type document in open access publication of educational technology are article (72.4\%) 1.213 documents, then coference paper (12.2\%) 205 documents, review (6.8\%) 114 documents, editorial (3.7\%) 62 documents, note (1.8\%) 30 documents, letter (1.3\%) 21 documents, short survey (0.8\%) 14 documents, erratum $(0.7 \%) 12$ documents, and book chapter $(0.2 \%) 3$ documents.

\section{Most Frequent Institution Affiliation of Educational Technology Publication}

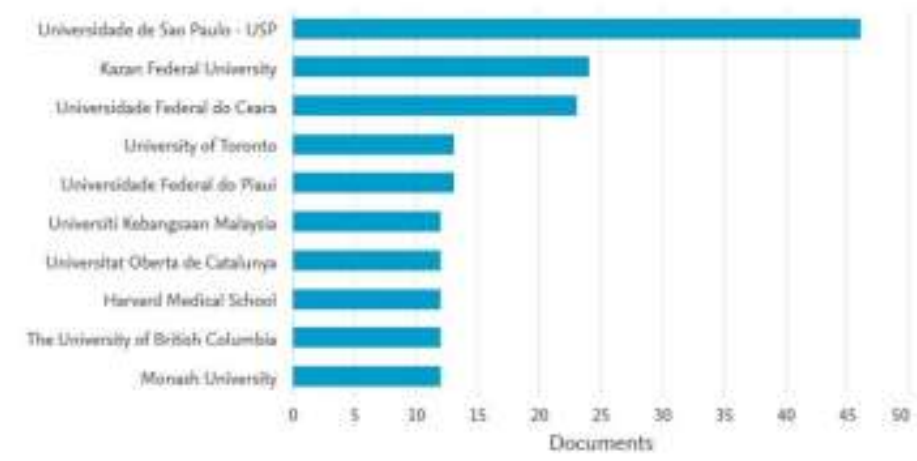

Figure 7. Affiliation Number of Educational Technology Per Year

Figure 7 shows the top 10 research institutions in open access publications in the field of Educational Technology that is led by Universidade de São Paulo with 46 documents. Followed by Kazan Federal University (24), Universidade Federal do Ceara (23), University of Toronto (13), Universidade Federal do Piaui (13), Universiti Kebangsaan Malaysia (12), Universitat Oberta de Catalunya (12), Harvard Medical School (12), The University of British Columbia (12) and Monash University (11).

\section{Most Frequency of Educational Technology Research by Subject Area}

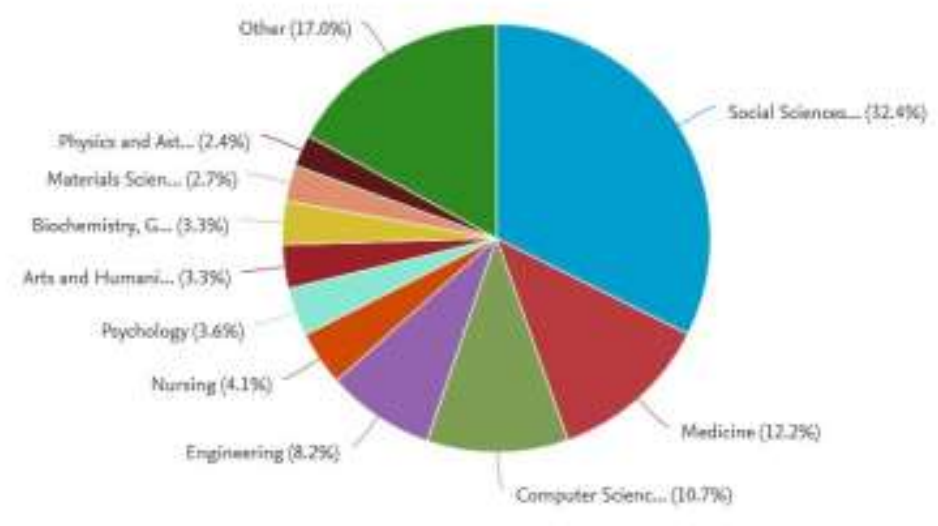

Figure 8. Most Frequency of Educational Technology Research by Subject Area

The most subject area in open access educational technology publications in social sciences 853 documents (32.4\%). Followed by other (17\%), medicine (12.2\%) 321 documents, Computer Science (10.7\%) 282 documents, Engineering (8.2\%) 215 documents, Nursing (4.4\%) with 109 documents, Psychology (3.6\%) 96 documents, Arts and Humanities (3.3\%) 87 documents, Biochemistry, Genetics and Molecular Biology (3.3\%) 86 documents, Material Science (2.7\%) 72 documents, Physics and Astronomy (2.4\%) 64 documents.

\section{Keyword Network}

There are 5 clusters of research keywords related to the field of educational technology.

1. Red Cluster - sub-topic: medical Education, review, priority journal, organization, and management.

2. Green Cluster - sub-topic: educational technology, student, teaching material, virtual reality.

3. Blue Cluster - sub-topic: a controlled study, human experiment, female. 
4. Yellow Cluster - sub-topic: internet, research, data analysis, science, editorial.

5. Purple Cluster - sub-topic: video recording, digital Education, a dental student.

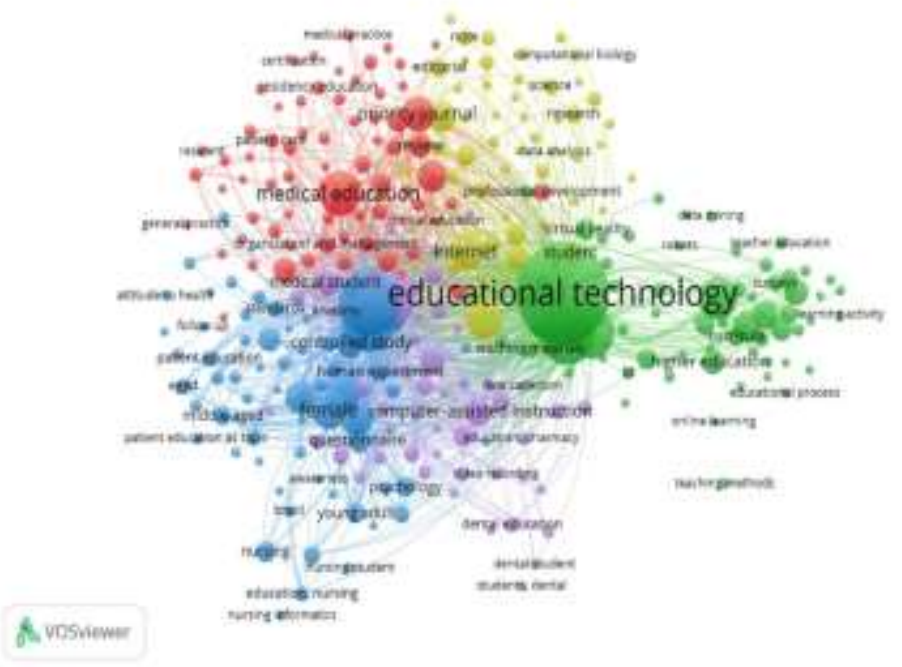

Figure 9. Keyword Network

\section{Year Documents Based on Sources of Educational Leadership Publications}

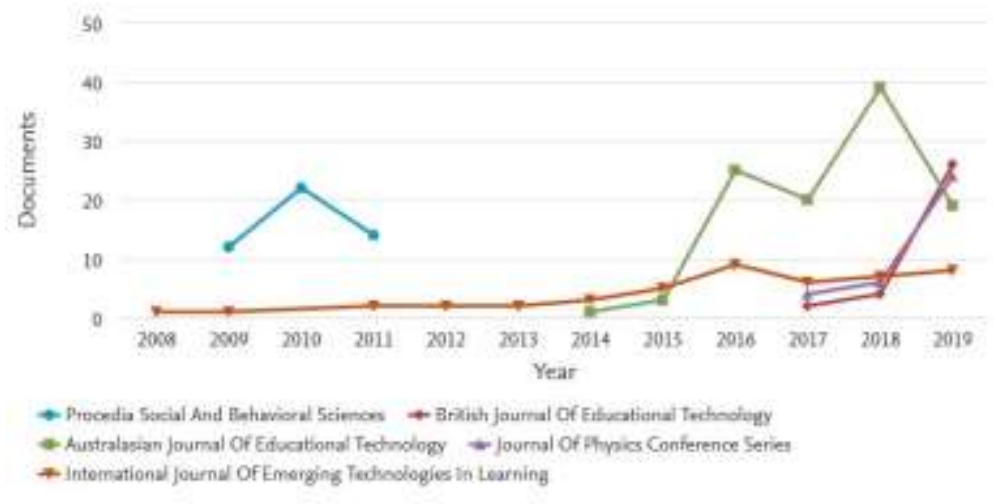

\section{Figure 10. Year Documents Based on Sources of Educational Leadership Publications}

The number of documents per year based on sources in international open access publications in educational technology is the Australasian Journal of Educational Technology with 107 documents. It is followed by Procedia Social And Behavioral Sciences 48 documents, International Journal of Emerging Technologies in Learning 46 documents, Journal of Physics Conference Series 34 documents, and British Journal of Educational Technology 32 documents.

\section{CONCLUSION}

The study results indicate that the work of Kamel Boulos, M.N., Maramba, I., Wheeler, S. in 2006, entitled Wikis, blog, and podcast: A new generation of Web-Based tools for virtual collaborative clinical practice and Education is the most cited international publications. Six hundred sixty-eight documents cite it. There is an increasing trend of international research in educational technology every year. The individual authors and affiliated institutions with the most publications are Peres, H.H.C., ten documents, and Universidade de Sao Paulo. There is only one author group collaboration pattern, so the number of research collaboration groups between researchers needs to be increased. The United States dominates research in the field of educational technology. The most frequent type document, subject area, and source in open access publication of 
educational technology is an article, social sciences 853 documents (32.4\%), and Australasian Journal of Educational Technology. There were 5 clusters of research keywords related to the field of educational technology. Further research should be done to analyze the contribution and impact of research by measuring citations based on a combination of Scopus \& WoS data.

\section{ACKNOWLEDGMENTS}

We would like to thank our parents, family, Nahdlatul Ulama, and Indonesia.

\section{REFERENCES}

Abdullah, Al, and Mamun Bhuiyan. "The Journal of Educational Development Financing Education : A Route to the Development of a Country." The Journal of Educational Development, vol. 7, no. 3, 2019, pp. 209-17, https://journal.unnes.ac.id/sju/index.php/jed/article/view/31323/14948.

Alison, Yasaman, and Ömer Delialioğlu. "The Effect of Authentic M-Learning Activities on Student Engagement and Motivation." British Journal of Educational Technology, vol. 50, no. 2, Mar. 2019, pp. 655-68, doi:10.1111/bjet.12559.

Appleton, James J., et al. "Student Engagement with School: Critical Conceptual and Methodological Issues of the Construct." Psychology in the Schools, vol. 45, no. 5, May 2008, pp. 369-86, doi:10.1002/pits.20303.

Barak, Miri. "Are Digital Natives Open to Change? Examining Flexible Thinking and Resistance to Change." Computers \& Education, vol. 121, June 2018, pp. 115-23, doi:10.1016/j.compedu.2018.01.016.

Bond, Melissa, et al. "Mapping Research in Student Engagement and Educational Technology in Higher Education: A Systematic Evidence Map." International Journal of Educational Technology in Higher Education, vol. 17, no. 1, International Journal of Educational Technology in Higher Education, Dec. 2020, p. 2, doi:10.1186/s41239-019-0176-8.

Chaka, Chaka, and Tlatso Nkhobo. "Online Module Login Data as a Proxy Measure of Student Engagement: The Case of MyUnisa, MoyaMA, Flipgrid, and Gephi at an ODeL Institution in South Africa." International Journal of Educational Technology in Higher Education, vol. 16, no. 1, Dec. 2019, p. 38, doi:10.1186/s41239-019-0167-9.

Choi, Moonsun, et al. "What It Means to Be a Citizen in the Internet Age: Development of a Reliable and Valid Digital Citizenship Scale." Computers \& Education, vol. 107, Apr. 2017, pp. 100-12, doi:10.1016/j.compedu.2017.01.002.

Czerniewicz, Laura, et al. "Online Teaching in Response to Student Protests and Campus Shutdowns: Academics' Perspectives." International Journal of Educational Technology in Higher Education, vol. 16, no. 1, Dec. 2019, p. 43, doi:10.1186/s41239-019-0170-1.

Davis, Lauren Dotson. "Common Core and the Continued Socioeconomic Achievement Gap: How Can We Better Prepare Future Teachers?" Journal of Education and Learning, vol. 8, no. 6, 2019, p. 1, doi:10.5539/jel.v8n6p1.

Iskandar, Akbar, et al. "The Effects of Multimedia Learning on Students Achievement in Terms of Cognitive Test Results." Journal of Physics: Conference Series, vol. 1114, Nov. 2018, p. 012019, doi:10.1088/17426596/1114/1/012019.

James Baxter, Gavin. "Implementing Web 2.0 Tools in Organisations." The Learning Organization, edited by Dr. Gavin J. Baxter, vol. 21, no. 1, Jan. 2014, pp. 2-5, doi:10.1108/TLO-08-2013-0042.

Jamilah. "The Effectiveness of English as a General Course Program at Yogyakarta State University." Journal of Education, vol. 1, no. 1, 2016, pp. 1-9.

Medina, F. Xavier, et al. "Feeding the Online: Perspectives on Food, Nutrition and the Online Higher Education." International Journal of Educational Technology in Higher Education, vol. 16, no. 1, Dec. 2019, p. 42, doi:10.1186/s41239-019-0173-y.

Natakusumah, Engkos Koswara. "Bibliometric Analysis of the Inkom Journal (Analisis Bibliometrik Journal Inkom)." Baca: Journal Documentstasi Dan Informasi, vol. 36, no. 1, 2016, p. 1, doi:10.14203/j.baca.v36i1.199.

Newman, Russell, et al. "Web 2.0-The Past and the Future." International Journal of Information Management, vol. 36, no. 4, Aug. 2016, pp. 591-98, doi:10.1016/j.ijinfomgt.2016.03.010.

Oliver, Beverley, and Trina Jorre de St Jorre. "Graduate Attributes for 2020 and beyond: Recommendations for Australian Higher Education Providers." Higher Education Research \& Development, vol. 37, no. 4, 
June 2018, pp. 821-36, doi:10.1080/07294360.2018.1446415.

Setyawati, Irma, et al. "A Visual Trend of Literature on Ecopreneurship Research Overviewed within the Last Two Decades." Journal of Entrepreneurship Education, vol. 21, no. 4, 2018, pp. 1-7.

Suci, Sayyida Hanim Ahida, et al. "Learning from Picture and Picture Action Research: Enhancement of Counting Ability on Division of Numbers for Primary School Students." Journal of Physics: Conference Series, vol. 1114, Nov. 2018, p. 012044, doi:10.1088/1742-6596/1114/1/012044.

Sutherland, et al. "Nanotechnologies: Principles, Applications, Implications, and Hands-on Activities." European Commission, European Commission, 2012, doi::10.2777/76945.

Widyasari, Yohana Dewi Lulu, et al. "Persuasive Technology for Enhanced Learning Behavior in Higher Education." International Journal of Educational Technology in Higher Education, vol. 16, no. 1, Dec. 2019, p. 15, doi:10.1186/s41239-019-0142-5. 